NBER WORKING PAPER SERIES

THE EFFECT OF TRADE UNIONISM

ON FRINGE BENEFITS

R. B. Freeman

Working Paper No. 292

NATIONAL BUREAU OF ECONOMIC RESEARCH

1050 Massachusetts Avenue

Cambridge MA 02138

October 1978

I have benefitted from the research assistance of Casey Ichniowski and John Rivin and the comments of Gary Chamberlain. The research reported here is part of the NBER's research program in Labor Studies. Any opinions expressed are those of the author and not those of the National Bureau of Economic Research. 


\section{ABSTRACT \\ The Effect of Trade Unionism on Fringe Benefits}

This paper analyzes the impact of unionism on the fringes paid bluecollar workers using data on individual establishments. The main substantive finding is that trade unionism raises the fringe share of compensation, particularly pension and life, accident and health insurance. The magnitude of the effect is sufficiently large as to suggest that estimates which neglect fringes understate the union effect on compensation. The paper uses the data on the compensation of blue-collar and white-collar workers within an establishment to control for within-establishment pay policies and estimate the potential effect of blue-collar unionism on the fringes of white-collar workers.

Professor Richard B. Freeman National Bureau of Economic Research 1050 Massachusetts Avenue Cambridge, Massachusetts 02138 (617) $868-3915$ 
Does collective bargaining alter the composition of the compensation packago received by workers? Is the fraction of the wage bill spent on "fringe benefits" higher in union than in nonunion firms, and if so, why?

Despite considerable public attention given to the fringe benefits negotiated by major unions and numerous studies of the effect of unions on wages, the impact of collective negotiations on the composition of the wage bill has received relatively littlc professional attention. While most labor economists believe that unions increase fringe benefits, the only substantive empirical analysis of the determination of fringes (Rice 1966) found little evidence of a sizeable union impact. With firm size and wages, among other factors, held fixed, Rice's regressions across industries yielded generally insignificant coefficients on the percentage organized. Reviewing the evidence, Reynolds concluded that much of the increase in fringes in recent years was probably attributable to 'voluntary employer action' and that "the specific influence of unionism is hard to determine" (Reynolds, pp. 216-217).

In this paper I use more detailed and disaggregate data from individual establishments to show that, contrary to the gross cross-industry results, unionism does in fact significantly raise the fringe share of the wage bill, and explore in detail the nature of this effect. The main source of data is the Expenditures for Employee Compensation (EEC) survey of the Bureau of Labor Statistics, which contains statistics on the compensation of office and nonoffice (production) workers in private nonfarm establishments. ${ }^{1}$ By providing information on two types of workers within an establishment, one of whom (office workers) is rarely organized, the EEC data permit some methodological advances in the estimation of union effects. Within-establishment differences in compensation can be used as units of observation, eliminating the potential effects of "unobserved" firm factors in much the same way as comparisons 
of "brothers" or twins eliminates family background effects in the analysis of earnings among individuals (see Chamberlain). In addition, it is possible to exploit the establishment data to estimate models in which unionism of production workers induces firms to raise the fringes paid office workers within the establishment. These methodological innovations have a substantive effect on the magnitude of the estimated impact of unionism. The paper is divided into five parts. Section one sets out theoretic and institutional reasons for expecting unionism to alter the composition of the labor compensation package. Section two describes the data set used and issues covered in the empirical work. Section three presents estimates of the union effect from regressions across establishments. Section four develops more complex models that allow for unobserved firm effects and spillovers within establishments. The paper concludes with a brief evaluation of the significance of the findings for the economic analysis of unions.

\section{Unionism and Fringe Benefits}

The division of a dollar of compensation per-man hour between fringe behefits and straight-time pay can be fruitfully analyzed in terms of the effective supply price of fringes, defined as the wage workers would forego to obtain the benefit. The higher the supply price the greater the probability of providing a given fringe and the greater its share of compensation.

There are several reasons for expecting trade unionism to raise the effective supply price of fringes.

The most important reason is that unions are political as well as economic institutions, whose behavior must be consonant with the desires of a majority of workers. In a world in which some workers are more or less permanently attached to firms (for reasons of transactions costs of mobility) while others are more mobile or marginal, the union will give 
greater weight to the preferences of the older, relatively permanent employees than would occur in a competitive market, where the desires of the marginal employee set the supply price. In the context of the median voter model, the union would represent the tastes of the median worker, as opposed to the marginal worker. If, as seems reasonable, older presumably less mobile workers have greater desires for fringes (see Nealey for evidence), the supply price and provision of fringes will be greater under collective than individual bargaining.

Formally, represent the postulated differential attachment of workers to firms by an upward sloping supply schedule dependent on wages $(w)$ and fringes ( $f$ )

(1) $L(w, f) L_{w}>0 \quad L_{f}>0$

The inverse function of (1) relating wages to fringes and employment defines the supply price of fringes:

(2) $w(f, L) w_{f}<0 \quad w_{L}>0$

Fa ced with this supply price, cost minimization by the firm requires for any given $\mathrm{L}$ an interior solution $\mathrm{f}$ * such that a dollar of fringes reduces the marginal wage cost of labor by the same amount: ${ }^{2}$

(3) $\mathrm{W}_{\mathrm{f}}(\mathrm{f} *, \mathrm{~L})=-1$

The firm will provide a given fringe $f_{i}$ when at the optimal value $f_{i}^{*}$ the reduction in wages exceeds expenditures on the fringe and the average fixed cost $(\bar{c} / \mathrm{L})$ of instituting the program:

(4) $w(0, L)-w\left(f_{i}^{*}, L\right) \geq f_{i}^{*}+\bar{c} / L$

According to (3) expenditures on fringes in a nonunion setting depend on the marginal evaluation of fringes by the marginal worker, $w_{f}(f, L)$. According to (4) initiation of a particular benefit depends on the change in wages $w(O, L)-w\left(f{ }_{i}^{*}, L\right)$ exclusive of any potential infra-marginal 'worker surplus.' 
By contrast, the supply price set by the union will depend on the operation of the union as a political entity and the resultant union maximand. In this paper I consider two schematic models of union behavior: a median voter model and an 'optimizing cartel' model. Under both models and reasonable mixtures or variants thereof, it can be demonstrated that the supply price of fringes will be higher under unionism.

Consider first the case in which the union seeks to maximize the preference function of the median worker. If all workers are ordered from 0 to $\mathrm{L}$ in terms of greatest to least attachment to the firm, the supply price function will be $w(f, L / 2)^{3}$. Cost minimization by the union firm leads to the interior solution $\mathrm{f}^{\mathrm{m}}$ that sátisfies:

(5) $\mathrm{w}_{\mathrm{f}}\left(\mathrm{f}^{\mathrm{m}}, \mathrm{L} / 2\right)=-1$

and to the condition for introducing the fringe $f_{i}$ of

(6) $W(0, L / 2)-w\left(f_{i}^{m}, L / 2\right)>f_{i}^{m}+\bar{c} / L$

If, as assumed, marginal workers have less desire for fringes than inframarginal workers, $w_{f}(f, L / 2)<w_{f}(f, L)$. As a consequence $f^{m}>f *$ and the union firm will spend more on fringes and be more likely to introduce particular programs than the nonunion firm.

As an alternative, consider the behavior of a union which, for reasons of logrolling and internal redistribution of benefits among members, operates like an optimizing cartel. Such a union will be assumed to maximize total worker surplus, defined as the area above the supply curve: ${ }^{4}$

(7) $\operatorname{Lw}(f, L)-\int_{0}^{L} w(f, x) d x$

Maximization requires an interior solution $f^{c}$ that satisfies:

(8) $w_{f}\left(f^{c}, L\right)-\frac{1}{L} \int_{0}^{L} w_{f}\left(f^{c}, x\right) d x=0$

where $\frac{1}{L} \int_{0}^{L} w_{f}\left(f^{c}, x\right)$ is the average supply price of the fringe, and the condition for providing the fringe $f_{i}$ :

(9) $1 / L \int_{0}^{L} w(f, x) d x>f_{i}^{c}+c / L$. 
When the average supply price is greater (in absolute value) than the marginal supply price $f^{c}$ will exceed $f *$. When the 'average surplus,' $1 / L f_{0}^{L} w(f, x) d x$, exceeds the saving in wages $w(0, L)-w\left(f_{1} L\right)$, the union firm will be more likely to initiate particular programs. Both of these conditions hold when $w_{f L}<0$, i.e. when, as postulated, marginal workers have less desire for fringes than infra-marginal workers.

Although both the median voter and optimal cartel models represent polar cases, which ignore the numerous complexities of union behavior, they do shed light on the difference between the supply price of fringes under collective and individual bargaining. The prediction of greater allocation of funds to fringes under unionism does not depend on the precise model of union behavior but rather on the broad principle that, as political institutions, union are likely to weigh more heavily than nonunion firms the preferences of infra-marginal workers who tend to be especially desirous of fringes.

Additional routes of the union effect

Trade unionism is likely to raise the supply price of fringes in several other ways as well. First, by increasing the length of the attachment between workers and firms (raising job tenure and lowering quit rates), unionism ralses the likelihood that workers will receive deferred fringes such as nonvested pensions or insurance health benefits. As a result the value of these fringes will be greater under unionism, increasing their supply price and, all else the same, dollar expenditures.

Second, in sectors of the economy where workers are attached to occupations rather than employers (i.e. construction) or where enterprises are short-lived (garment trade) or where firms are relatively small (trucking) unions provide the type of large permanent market institution needed to operate most fringe programs. Without unions (or some comparable structure) the probability of receiving deferred benefits would be too 
small and the fixed costs too high for most benefits to be economically sensible. What is needed are multi-employer programs, of the type inftiated by unions in the aforementioned industries, which vest benefits across employers and provide the size to reduce average set up costs. In just such a manner did unions operate as fraternal benefit societies years ago. Third, as argued by Freeman (1976), Nelson (1976) and Hirschman (1976), unions may elicit more accurate information about workers preferences for fringes than can be gained from individual bargaining. Given high income elasticities for fringes, this should lead to more rapid and greater provision in the organized sector. Conceptually, the adversary relation between employers and employees -- the fact that the level as well as allocation of the compensation package is at stake -- argues for circumspection in provision of information by workers. If employers had complete knowledge of employee preference functions, they would seek to extract all of the worker surplus, striking a bargain that would leave workers at their minimum acceptance point. ${ }^{5}$ It might be better for employees to withhold information. As the agent of workers, on the other hand, unions should obtain a more accurate revelation of preferences through the internal process of bargaining over the appropriate acceptable pay package, and may play an especially important role in eliciting desires for fringes that are 'public' to the work force. Empirically, there is some evidence that information factors are important in differentiating union and nonunion firms in the fringe area. Richard Lester's 1967 review of surveys of managerial perceptions of worker preferences found "limited data... that workers value benefits more highly compared to wages than employers believe their workers do" (p. 494) while Edward Lawler's study of union leaders concluded that leaders are generally good predictors of the members' preferences for various compensation packages, though they also seem to have understated the desire for fringes (p. 517). It may, in general, be more reasonable to expect accurate information flows 
to emerge from collective negotiation, despite bargaining tactics, than from exit interviews, questioning of individual workers, and the like, given the incentives to respond. 6

Fourth, the complexities involved in evaluating the costs and propective benefits of modern fringe benefits may make workers more willing to accept fringes when they have a specialized agent like a union evaluating and monitoring employer, claims and programs (Alchian \& Demsetz). Significant investments in knowledge which lie beyond the purview of individual workers are needed to judge the true cost and future benefits of alternative compensation packages. Union laẉyers, actuaries, and related experts are one institutional mechanism by which workers can obtain the expertise to bargain over these diverse benefits.

Finally, the fact that most fringe benefits have been ruled by the courts to be mandatory bargaining topics, whose lack of resolution can lead to impasses and strikes, is also likely to spur programs and expenditures in the union sector. Prior to the Supreme Court rulings on pensions (Inland Steel Case) and health and welfare funds (W.W. Cross Case) in 1949, companies often argued that such benefits were 'management gifts' and not the subject of negotiations. Since then fringes have become a major issue in almost all collective negotiations. While agreement need not be reached on these (or other) mandatory topics, the rulings have presumably impelled more serious negotiations and provisions than would have been the case if fringes had been ruled permissive topics.

In sum, unionism is likely to raise expenditures on fringes and the number of programs, particularly deferred benefits favorèd by older workers and those with high fixed costs, and to have especially large effects on small firms in industries with unstable employer-worker relations.

\section{Other determinants of fringes}

In addition to unionism, the fringe share of the wage bill is likely 
to depend on several other economic factors, whose influence must be held fixed in empirical work. Amont the most important are:

(1) Overall level of compensation. Fringes are likely to have a positive income elasticity and thus be correlated with total compensation per manhour. If the elasticity exceeds one, the fringe share of the wage bill will also be related positively to total compensation.

(2) Tax benefits of deferred compensation. Because money placed into pension and related plans is not taxed when payment is first made; earns interest that is not taxed until paid out; and is taxed at potentially favorable capital gains rates or as salary at lower income tax rates on retirement, the tax system reduces the cost of fringes and thus encourages expenditures on them. As a result of the tax advantages, the "income" elasticity of fringes with respect to before-tax income will be biased upward since the true effect of income will be confounded with the price effect due to increasing tax rates and tax 'savings' from fringes.

(3) Specific human capital. By creating an incentive for permanent employment relations, specific human capital will increase the fringe share of compensation. Workers will havè a higher supply price for fringes because of the likelihood of remaining with the firm. Firms will use deferred fringes, notably pensions, to discourage quitting by the specifically trained.

(4) Firm size. Two factors are likely to lead to greater fringes in larger firms: reduction in the cost of establishing fringe programs as the fixed cost is divided among more workers; and the greater tenure of workers with large firms due to possibilities of within-firm mobility.

(5) Demographic characteristics of workers. The supply price for fringes should vary among the population, depending on personal characteristics. Older workers tend to favor deferred fringes like retirement pay, medical and health insurance (Nealey). Women generally have less desire for fringes than men, in part because they are often covered by their husbands' pension and health plans (Herman). And so forth. 
inedical and health insurance (Nealey). Women generally have less destre

for fringes than men, in part because they are often covered by their husbands' pension and health plans (Herman). And so forth.

\section{Data and Econometric Issues}

The princlpal source of data for the empirical analysis is the Expenditures for Employee Compensation (EEC) Survey of the Bureau of Labor Statistics. The EEC is an establishment survey covering all large establishments in . the private nonfarm sector and a probabllity sample of smaller establishments. The survey has several advantages: it relates to establishments rather than more aggregate unfts; contains detalled information on the compensation package; differentlates between nonoffice (blue-collar or production) workers and office (white-collar) employees; and has an approprlate measure of unfonism, whether or not workers are covered by a collective bargaining contract. ${ }^{7}$ There are disarivantages also; because of confidentiality, the public data tapes exclude certain large firms: Obecause only enterprise data are obtalned, Information on the personal characteristics of workers is lacking; because the figures relate to costs rather than benefits, they provide imperfect measures of the value of fringes to workers. Even so, the detailed establishment compensation flgures make the EEC the best ava1lable data set for analysis of the effects of unionism on the compensation package.

The data from the EEC surveys of 1967-68, 1969-70, and 1971-72 were amalgamated into a single pooled sample, with monetary figures transformed Into comparable units by deflation to 1967 dollars on the basis of the level of avernge hourly earnings in the private sector. The pooled sample contalins 10,088 cstablishment observations.

Table 1 summarizes the data on the composition of compensation per manhour in the sample for unton and nonunion nonoffice workers in the 
Since some fringes are required by law and thus not amenable to collective negotiations, lines 4 and 5 divide the fringes into two basic types: the legally required, such as social security, unemployment insurance, and workmen's compensation; and voluntary fringes, which include vacation pay, holiday pay, pensions, life, accident and health insurance, sick leave, overtime pay, and several smaller benefits. While, as seems reasonable, there is little or no difference in the proportion of compensation spent on legally required fringes between union and nonunion establishments, there is a sizeable difference in the proportion going to voluntary fringes. In manufacturing, 19.1 percent of the wage bill in unionized establishments is spent on voluntary fringes compared to 13.3 percent of the wage bill in nonunion establishments. In all private industry, the porportions are 16.2 percent (union) and 10.6 percent (nonunion). Because voluntary fringes are the subject of labor-management negotiations, they will be the main dependent variable in ensuing empirical analyses.

\section{Independent variables}

To estimate the impact of unionism on the compensation package, it is important to control for diverse other factors (correlated with unionism) that can be expected to affect fringes. The EEC tapes contain several establishment variables that will be used as controls:

total compensation per man hour, which will control for income effects in the 'purchase' of fringes and isolate the effect of unionism on the composition as opposed to level of the wage bill

size of establishment, measured by nonoffice employment

region and SMSA dumy variables, which distinguish between four regions and size of place

industry dumy variables, entered to control for diverse differences, including technologically determined differences in specific human capital and differences in characteristics of workers. A large number of industry 
Table 1: Expenditures and Distribution of the Compensation of Nonoffice Workers, by Union Status, 1967-1972 (in 1967\$)

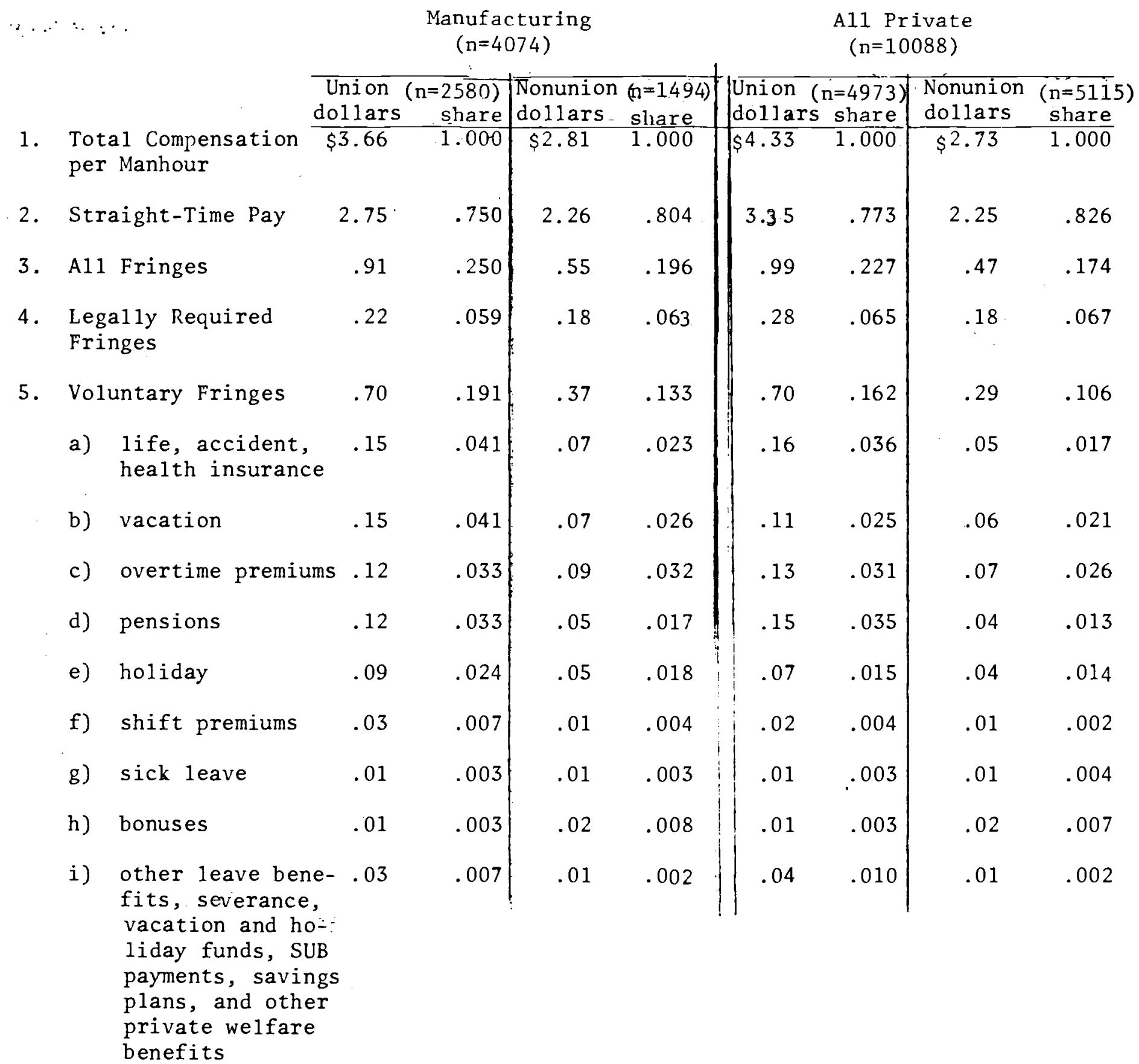

Source: Calculated from Bureau of Labor Statistics, Expenditures for Employee Compensation Survey, tapes 1967-68, 1969-70, 1971-72. Column sums do not always add to the correct total due to rounding. 
dummes will be used to focus on as similar groups of establishments as possible. The major problem with the establishment data set 1s a lack of information on the personal characteristics of workers within establishments, especially age, which can be expected to affect fringe payments. This problem is dealt with in three ways. First, by supplementing the EEC data with information from the Current Population Survey (CPS) on the characteristics of workers in detailed industries. Specifically, I tabulated from the May 1973, 1974 and 1975 CPS files the mean years of schooling, percent male, percent white, percents above 50 and below 30 years of age for union and nonunion production (and nonproduction) workers in three digit industries and added these figures to the EEC tapes. 9 Establishments in which production workers were organized were given the means for union workers in the three digit industry while establishments which were unorganized were given the means for nonunion workers. With different figures for organized and unorganized establishments in the same sector, the procedure controls for differences in the personal characteristics of union and nonunion workers within an industry but not for differences across individual establishments.

Second, in several calculations the ratio of office to nonoffice workers in an establishment was entered as a crude indicator of whether the enterprise had an assembly line (lower skill) nonoffice work force or a more highly skilled group of blue-collar employees. The ratio is expected to be higher when the blue-collar workers are relatively skilled because of the general pattern for industries with relatively many white-collar employees to have a more skilled blue-collar work force than those with a predominantly blue-collar work force. ${ }^{10}$

Third, as noted, extensive use is made of industry dummy variables to control for characteristics that have a significant industrial variation. While none of these procedures eliminates the problem of inadequate personal data, that is the price that must be paid for the advantages of establishment data files at present. 


\section{Econometric issues}

The effect of unionism and the other independent variables on fringes will be estimated with linear and $10 \mathrm{l}-1$ inear equations:

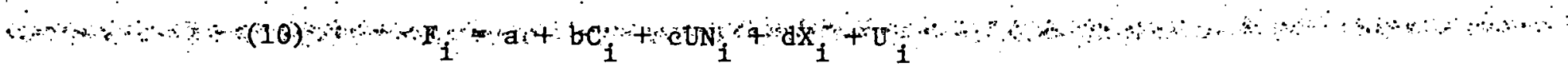

$$
\ln \mathrm{F}_{i}=a+b\left(\ln C_{i}\right)+c N_{i}+d \dot{X}_{i}+v_{i}
$$

where $F_{i}$ = voluntary fringes per man hour paid nonoffice (blue-collar) worker

$C_{i}=$ total compensation per man hour

$\mathrm{UN}_{i}=0-1$ dumn variable for collective bargaining coverage

$x_{i}=$ other control variable, for algebraic sirplictty only one $x_{i}$ is distinguished here.

$$
\begin{aligned}
& \mathrm{U}_{i}=\text { random disturbance } \\
& \mathrm{V}_{\mathrm{i}}=\text { random disturbance }
\end{aligned}
$$

The linear form is applied to the entire sample, including the small minority of firms (about 2 percent of the sample) which pay no voluntary fringes, and is also used to analyze specific fringes. where there are numerous zero values. The $10 \mathrm{~g}$ form is used in analyses which correct for omitted establishment factors and which treat interactions between unionism and other variables. It is applied to the establishments that have nonzero voluntary fringes.

There are two econometric problems with (10) and (11). The first is simultaneity due to the fact that total compensation includes fringes $\left[C_{i} \equiv F_{i}+S_{i}\right.$ where $S_{i}=$ straight-time pay], giving rise to the standard simultaneous bias from having the same variable on both sides of the equation. ${ }^{11}$ To correct for simultaneity in the linear form, $F_{i}+s_{i}$ is substituted for $c_{i}$ in (10) and the resultant equation solved for $F_{i}$ to obtain

$$
F_{i}=a / 1-b+(b / 1-b) S_{i}+(c / 1-b) U N_{i}+(d / 1-b) x+U_{i} / 1-b
$$


The structural parameters of concern can be obtained from (12) by solving the estimated coefficient on $S_{i}$ for $\hat{b}$ and multiplying the other parameters by $1-\hat{b}$. To correct for simultaneity in the $\log$ form, $\ln C_{i}$ will be $\therefore$ instrumented by lns (and the other varjables in (11)) and the instrument on used in place of $\ln C_{i}$ in the equation.

The second and potentially more serious econometric problem relates to the independence of $\mathrm{UN}_{i}$ (or the $\mathrm{X}_{i}$ variables) and the residual $\mathrm{U}_{i}$ or $\mathrm{V}_{i}$. If the residual includes an establishment component related to unionism, the coefficient on $\mathrm{UN}_{i}$ will be biased. If high fringe firms tend to be organized (say because they are leading enterprises), OLS estimates of (10) or (11) will overstate the union effect, and conversely if $E\left(V_{i} U N_{1}\right)<0$ or $E\left(U_{1} U N_{1}\right)<0$ The availability of data on office workers within an establishment can be used to treat this problem. If the omitted enterprise factor affects office as well as nonoffice workers, it will influence both fringes, permitting white-collar fringes to proxy the missing variable. Formally, when there is an enterprise specific omitted factor, the error in (11) can be divided into two parts, $v_{i}=\lambda h_{i}+\ell_{i}$ where $h_{i}$ is the firm effect, with a scaling factor $\lambda$, and where $\ell_{i}$ is the remainder of the residual. ${ }^{12}$ This gives tne following equation for nonoffice worker fringes:

$$
\ln F_{i}=a+b \operatorname{lnC} C_{i}+\operatorname{cUN}_{i}+d x+\lambda h_{i}+l_{i}
$$

Now let the fringes of office workers $\left(F_{i}{ }^{w}\right)$ depend on their compensation $\left(C_{i}{ }^{w}\right)$, other controls $\left(X^{w}\right)$, the omitted factor with a scaling factor of 1,13 and a residual $\ell_{i}^{w}$ uncorrelated with the independent variables.

$$
\ln \left(F_{i}^{w}\right)=a^{w}+b^{w} \ln \left(C_{i}{ }^{w}\right)+d^{w} x^{-}+\cdot h_{i}+\ell_{i}^{w}
$$

where the $w$ superscripts relate to the office or white-collar workers and Where the different scalings of the firm effect in (13) and (14) permits the firm factor to affect white-collar workers differently from blue-collar workers. The firm specific component $h_{i}$ can be eliminated from (13) by multiplying (14) by $\lambda$ and substituting for $\lambda \mathrm{h}_{i}$ to obtain 
(15)

$$
\ln \left(F_{i}\right)=\lambda \ln \left(F_{i}{ }^{w}\right)+c J N_{i}+b\left(\operatorname{lnc} C_{i}-\lambda b^{w} \ln \left(C_{i}{ }^{w}\right)+\left(d-\lambda d^{w}\right) x+\ell_{i}-\lambda l_{i}{ }^{w}\right.
$$

Least squares estimates of (15) will not yield unbiased or consistent parameter estimates, since the residual $-\lambda \ell_{i}{ }^{w}$ is negatively correlated with $1 \mathrm{nF}{ }_{i}{ }^{\mathrm{w}}$. The

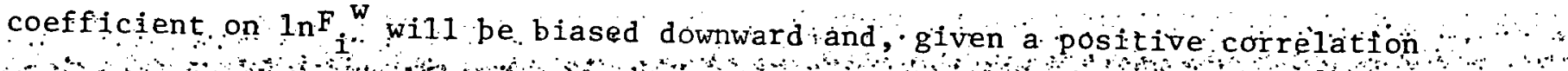
between $\ln F_{i}$ and $U N_{i}$, the union coefficient will be biased upward. While there is no easy way around this problem, ${ }^{14}$ the extent of the bias can. be evaluated using standard bias formulae. If $\ln F_{i}{ }^{w}$ and $\mathrm{UN}_{i}$ are only modestly correlated (as turns out to be the case), the bias will be quite small and the resultant estimate on $\mathrm{UN}_{i}$ presumably close to the correct value.

Finally, to the extent that as industrial relations experts like slichter, Livernash and Healy claim "to some degree union plant workers have-become pattern setters for office groups" (p. 445), the model embodied in (15) provides an extremely stringent test of the impact of collective bargaining on blue collar fringes. It uses expenditures on white collar fringes(relative to expected expenditures) as a proxy for the omitted establishment component without allowing blue collar unionism to affect the white collar fringes. If unionized firms pay higher fringes to white-collar workers to forestall organization and minimiz̈e worker discontent, estimates of the impact of uniorism that "correct" for omitted firm factors as in (15) will understace the true union effect on production workers by misallocating the union effect. An effort is made in section IV to modify the model to allow for the possible impact of unionism on the fringes of white-collàr workers.

\section{Basic Cross-Establishment Est1mates}

This section presents least squares estimates of fringe equations (12)-(15), using cross-establishment data. It finds that, with total compensation held fixed, unionism significantly raises fringe spending, particularly on life, accident \& health insurance, pensions, vacation, and holiday pay, and has its greatest impact on small low-wage firms. Since the calculations control for total compensation, the effect cannot be 
attributed to union monopoly wage gains but appears rather to represent the more complex aspects of union behavior discussed in section. I.

The linear model

an $\cdots \cdots$

Table 2 presents estimates of the impact of unionism on fringe benefits using linear equations (10) and (12) for the entire private nonfarm sector and for the manufacturing subsector of the EEC sample. Lines 1-4 record the coefficient and standard error for unionism, compensation, and size of establishment (in terms of nonoffice worker employment); 1ines 5-9 list the other control variables while the remaining lines give the summary statistics. Colum I records means of the explanatory variables for all private industry, while Column 2 presents estimates of equation (10) ffor all private industry. The union coefficient is a moderate but highly significant .056 , indicating that establishments which are organized pay nearly $6 \mathrm{c}$ more per manhour for fringes. Because of the simultaneity problem, however, this is likely to be an underestimate of the effect of unionism on fringes with compensation held fixed. Columns 3- 4 correct for simultaneity by replacing total compensation per manhour by straight-time pay plus required fringes on the right-hand side of the equation. The coefficients in the new regression, given in column 3, represent the structural parameters divided by $1-b$, where $\mathrm{b}$ is the parameter on compensation. Column 4 gives the estimated structural parameters, obtained by solving for $\hat{b} \hat{b} / 1-\hat{b}=.104)$, and multiplying coefficients by $1 \hat{-b}$. As expected, the simultaneity correction raises the estimated impact of unionism markedly, from $5.6 \mathrm{c}$ in (2), to $10.1 \mathrm{c}$ in (4). At the mean level of spending on voluntary fringes in the sample of $49 \mathrm{c}$, the final estimate translates into an elasticity of fringes with respect to unionism of .2I (= 10.1/49). The calculations in columns (6)-(8) give a similar result for the manufacturing subsector, with a final simultaneity corrected estimate of $7.8 \mathrm{c}$ or 13 percent of the mean voluntary fringes of $58 \mathrm{c}$ per manhour in the sample. 
Table 2

Regression Estimates of the Impact of Collective Bargaining on Voluntary Fringes (in \$ thour) paid to Nonoffice Workers, 1967-197: $2^{\mathrm{a}}$

Other Controls

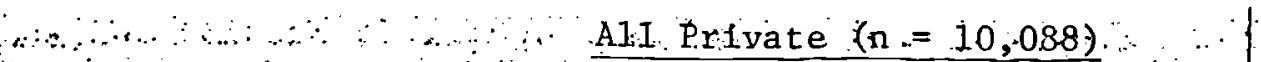

\begin{tabular}{|c|c|c|c|c|c|c|c|c|c|}
\hline \multirow{3}{*}{\multicolumn{2}{|c|}{$\therefore$}} & \multirow{3}{*}{$\begin{array}{l}\text { Mean and } \\
\text { Standard } \\
\text { Deviation } \\
\text { (1) }\end{array}$} & \multicolumn{3}{|c|}{$\because$ Teast } & \multicolumn{4}{|c|}{ Mèan and } \\
\hline & & & \multicolumn{2}{|c|}{$\begin{array}{c}\text { Squares } \\
\text { Coefficients }\end{array}$} & \multirow{2}{*}{$\begin{array}{c}\text { Structural } \\
\text { Parameters } \\
\text { (4) }\end{array}$} & \multirow{2}{*}{$\begin{array}{l}\text { Standard } \\
\text { Deviation } \\
\text { (5) }\end{array}$} & \multicolumn{2}{|c|}{$\begin{array}{c}\text { Squares } \\
\text { Coefficients }\end{array}$} & \multirow{2}{*}{$\begin{array}{l}\text { Structural } \\
\text { Parameters } \\
\text { (8) }\end{array}$} \\
\hline & & & $(2)$ & (3) & & & $(6)$ & (7) & \\
\hline \multicolumn{10}{|c|}{ Independent Variable } \\
\hline 1) & $\begin{array}{l}\text { Collective } \\
\text { bargaining }\end{array}$ & $\begin{array}{l}.49 \\
(.50)\end{array}$ & $\begin{array}{l}.056 \\
(.008)\end{array}$ & $\begin{array}{l}.117 \\
(.009)\end{array}$ & .101 & $\begin{array}{l}.63 \\
(.48)\end{array}$ & $\begin{array}{l}.048 \\
(.009)\end{array}$ & $\begin{array}{l}.096 \\
(.012)\end{array}$ & .078 \\
\hline 2) & $\begin{array}{l}\text { Total compensa- } \\
\text { tion per } \\
\text { manhour }\end{array}$ & $\begin{array}{r}3.52 \\
\therefore(1.59)\end{array}$ & $\begin{array}{l}.200 \\
(.002)\end{array}$ & & .133 & $\begin{array}{l}3.35 \\
(1.00)\end{array}$ & $\begin{array}{l}.260 \\
(.004)\end{array}$ & & .184 \\
\hline 3) & $\begin{array}{l}\text { Straight-time } \\
\text { pay plus re } \\
\text { quired fringes } \\
\text { per manhour }\end{array}$ & $\begin{array}{c}3.02 \\
(1.33)\end{array}$ & & $\begin{array}{l}.154 \\
(.003)\end{array}$ & & $\begin{array}{l}2.77 \\
(.72)\end{array}$ & & $\begin{array}{l}.224 \\
(.006)\end{array}$ & \\
\hline 4) & $\begin{array}{l}\text { Nonoffice em- } \\
\text { ployment (in } \\
\text { hundreds) }\end{array}$ & $\begin{array}{c}5.26 \\
(16.00)\end{array}$ & $\begin{array}{l}.018 \\
(.002)\end{array}$ & $\begin{array}{l}.024 \\
(.002)\end{array}$ & .021 & $\begin{array}{c}7.58 \\
(16.14)\end{array}$ & $\begin{array}{l}.022 \\
(.002)\end{array}$ & $\begin{array}{l}.035 \\
(.002)\end{array}$ & .029 \\
\hline
\end{tabular}

5) Industry dummies

50

50

6) Region, SMSA dumnies

7) Year dummies

8) ${ }^{b}$ Average characteristics of workers: years of school; \% white; $\%$ male; \% less than 30 ; $\%$ greater than 50

9) Office to nonoffice employment

Summary Statistics

\begin{tabular}{|c|c|}
\hline $\mathrm{R}^{2}$ & .696 \\
\hline SEE & .225 \\
\hline
\end{tabular}

\begin{tabular}{|c|c|c|c|}
\hline \multirow{2}{*}{$\begin{array}{l}\text { Standard } \\
\text { Deviation } \\
\text { (5) }\end{array}$} & \multicolumn{2}{|c|}{$\begin{array}{c}\text { Squares } \\
\text { Coefficients }\end{array}$} & \multirow{2}{*}{$\begin{array}{c}\text { Structural } \\
\text { Parameters } \\
\text { (8) }\end{array}$} \\
\hline & (6) & (7) & \\
\hline $\begin{array}{l}.63 \\
(.48)\end{array}$ & $\begin{array}{l}.048 \\
(.009)\end{array}$ & $\begin{array}{l}.096 \\
(.012)\end{array}$ & .078 \\
\hline $\begin{array}{c}3.35 \\
(1.00)\end{array}$ & $\begin{array}{l}.260 \\
(.004)\end{array}$ & & .184 \\
\hline $\begin{array}{l}2.77 \\
(.72)\end{array}$ & & $\begin{array}{l}.224 \\
(.006)\end{array}$ & \\
\hline $\begin{array}{c}7.58 \\
16.14)\end{array}$ & $\begin{array}{l}.022 \\
(.002)\end{array}$ & $\begin{array}{l}.035 \\
(.002)\end{array}$ & .029 \\
\hline & 20 & 20 & \\
\hline & 4 & 4 & \\
\hline & 5 & 5 & \\
\hline & $\checkmark$ & $\checkmark$ & \\
\hline & $\checkmark$ & $\checkmark$ & \\
\hline & .764 & .610 & \\
\hline & .174 & .224 & \\
\hline
\end{tabular}

a Dependent variable is dollars per manhour on voluntary fringes, as defined in Table 1. Independent variable measured in absolute units. Mean fringe for all private is $49 \mathrm{c}$. Mean fringe for manufacturing is $58 \mathrm{c}$.

$\mathrm{b}$ These variables were obtained at a 3 -digit industry level from the current Population Survey tapes for May 1973-75, with separate figures for union and nonunion workers, as described in text.

Source: Bureau of Labor Statistics, Expenditures for Employee Compensation Survey, tapes 1967-68, 1969-70, 1971-72. 
With respect to other variables, both compensation and size of establishment also positively influence expenditures on fringes. The simultaneity corrected estimate of the effect of an increase in compensation on fringes in all private industries is .133 , which at the mean vălue of compensation $(\$ 3.52)$ and voluntary fringe spending $-(\$ 29)$ translates into an olasticity $\because \ldots$ of $.96=[(.133 / .49) \times 3.52]$. Finally, while the coefficient on number of nonoffice workers is small in bbsolute value, because of substantial variation of employment in the sample, a standard deviation change in number of workers has a sizeable effect on fringes, raising them by $34 \mathrm{c}(=16.00 \times .021)$, which exceeds the effect of a one standard deviation change in total compensation of 21 ( $(=1.59 . \times 133)$.

The link between unionism and fringes is pursued further in Table 3 , which contains estimates of the effect of collective bargaining on fringes using the logarithmic form. The log equations are limited to establishments with nonzero voluntary fringes, a restriction which eliminates 37 manufacturing establishments and 243 total establishments, most of whom are nonunion. Column 1 records the results of regressing in voluntary fringes on the collective bargaining dummy for all private industry, with total compensation used to measure the size of the pay package. Unionism is accorded a highly significant positive coefficient of .109. Column 2 treats the problem of simultaneity between total compensation and fringes by instrumenting $\ln \mathrm{C}$ on $\ln$ straight-time pay: as would be expected the union coefficient rises while that on compensation falls. Column 3 examines the possibility that the union effect differs among firms with different levels of pay and size by interacting the collective bargaining variable with size of firm and total compensation. The interaction terms obtain sizeable significant coefficients that imply very different effects on smaller and lower paid establishments than on larger, higher paid establishments, as is indicated below: 
Table 3: Further Experiments on the Effect of Collective Bargaining on Voluntary Fringes Paid to Nonoffice Norkers, Using Log Form, 1967-1972 (standard errors are in parenthesis) ${ }^{\mathbf{a}}$

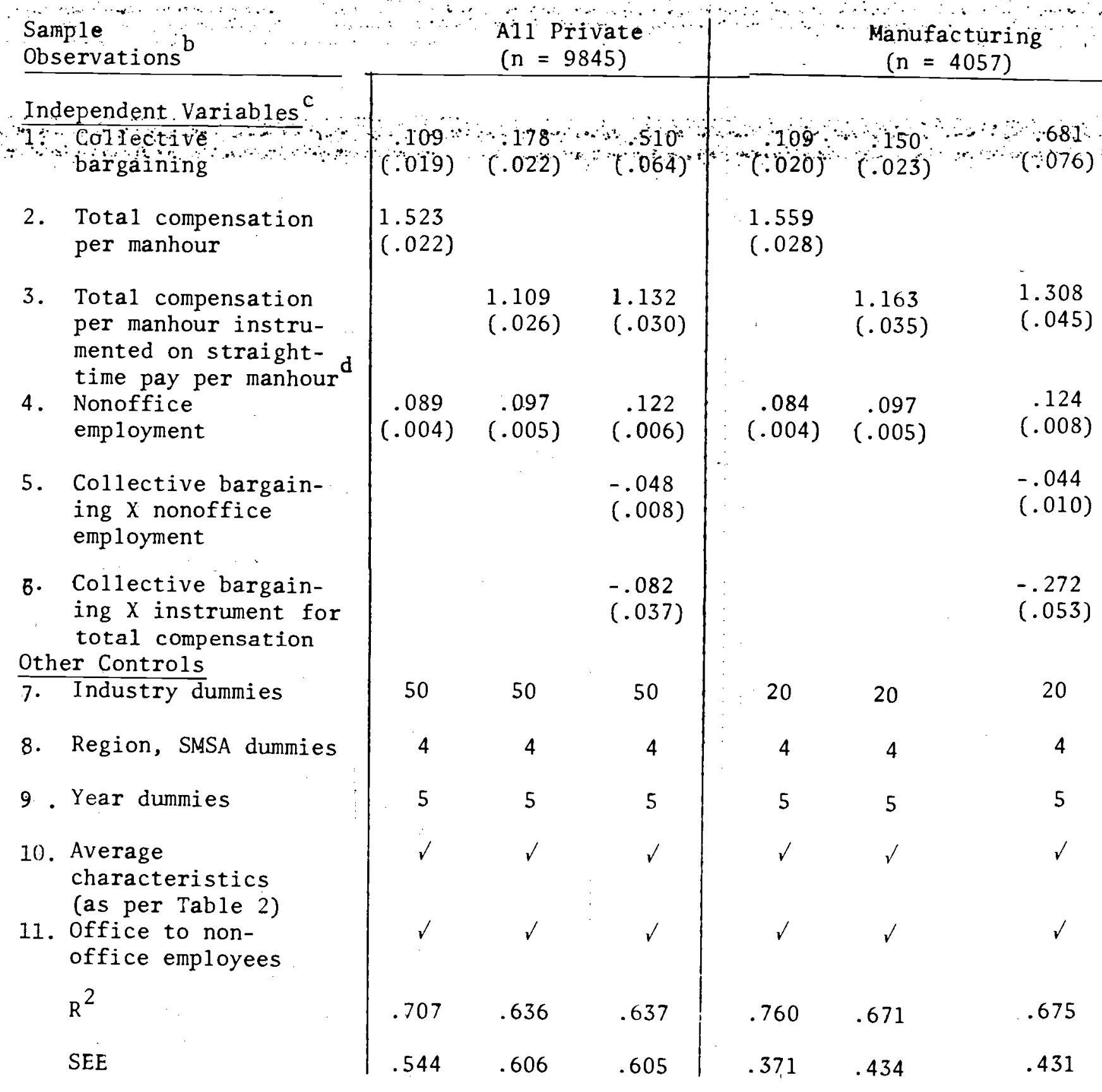

Notes: a Dependent variable is the ln of voluntary fringes paid per manhour, with voluntary fringes as defined in Table 1.

b 243 establishments were eliminated from the total private sample for paying no fringes; 17 : were eliminated from the manufacturing sample for paying no fringes. c Independent variables also in ln units, as specified.

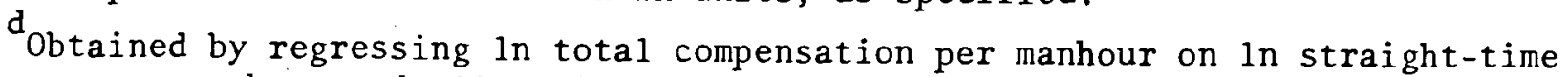
pay per manhour and all variables in the regressions, with separate estimates for all private and manufacturing samples.

Source: Calculated from Bureau of Labor Statistics, Expenditures for Employee CompenSation Survey. Tapes 1967-68, 1969-70, 1971-72. 
Union effect, by size and compensation

\begin{tabular}{l}
$\begin{array}{l}\text { One standard } \\
\text { deviation } \\
\text { below mean }\end{array} \quad \begin{array}{c}\text { One standard } \\
\text { deviation }\end{array}$ \\
\hline
\end{tabular}

size .292

.199 $: 106$

compensation $\because \quad \because \quad \because$

2350199

Source: Calculated from table 3 at mean levels of other variables.

Columns 4-6 of the table present similar computations for the manufacturing subsector. The results are essentially the same, with sizeable union effects in regressions 4 and 5, giving elasticities of fringe spending to unions of .109 , without the simultaneity correction and .150 with the correction. The interaction of bargaining with the size of the blue-collar work force in regression 6 parallels that for manufacturing in regression 3, while: the interaction with total compensation is larger.

All told, the results in Table 3 support the hypothesis that trade unionism influences the composition of the compensation package, raising the fringe proportion of wages, particularly in smaller firms, as predicted in section $I$, and in low wage firms as well.

\section{Specific fringes}

Which voluntary fringes are most affected by trade unionism? To what extent does the union effect operate by raising the likelihood that establishments will have a particular fringe prozram?

Table 4 presents calculations designed to answer these questions. Columns 1-2 record the cents per manhour spent on the major fringes in the average establishment and the proportion of establishments with the fringes. It shows that the most important fringes in terms of expenditures and availability are health, accident \& life insurance, vacation and holiday pay, overtime premiums, and pensions, with shift differentials, sick leave, and bonuses of nonnegligeable but lesser significance. Column 3 examines 


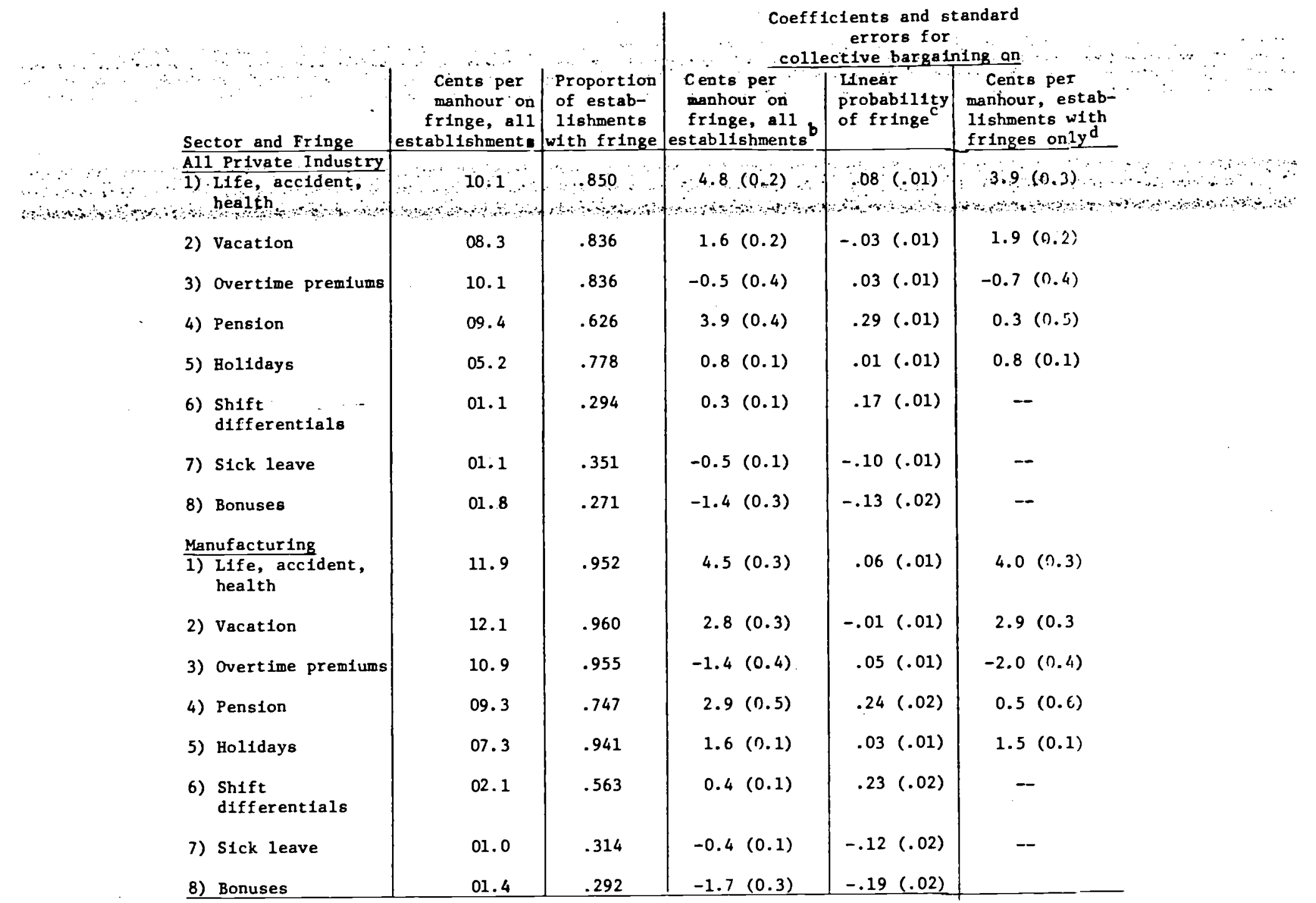

Notes: astimates in columns 3-5 are based on regressions with the following controls. For all private industry: 50 industry dumies, 3 region dumgles, 1 SMSA dummy, 5 year dumies, ratio of office to nonoffice workers, and 5 measures of average characteristics of workers: years of schooling, \% white, \% male, $\%$ less than 30 , and \% more than 50 years of age; straight-time pay pins required fringes per manhour; nonofice employment. For manufacturing industry: 20 industry dummies and all of the other controls used for the total private sector.

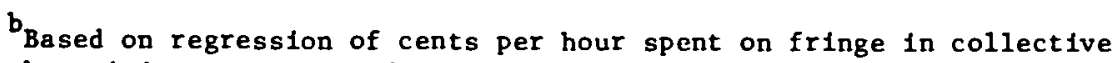
bargaining coverage and all control variables described in footnote a.

coefficient and standard error (in parenthesis) based on linear probab1lity regression of dichotomous measure of presence of fringes on collective bargaining coverage and all of the control variables described in footnote $a$.

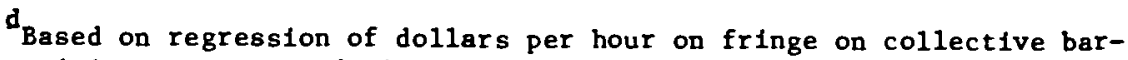
gaining coverage and all control variables described in footnote a with sample limited to establishments having the relevant fringe. Number of establishments = total number fringe group $X$ proportion given in column 1 . 
the impact of collective bargaining on expenditures for the mean fringes using the linear model (12), with straight-time pay plus required fringes as the measure of compensation and with all the variables listed in Table 2 used as controls. Because each fringe is too small to create a simultaneity problem, the column records the actual regression coefficients, rather than the simultaneity corrected structural parameters. The regressions show that unions have their greatest positive effect on deferred compensation in the form of pensions; on life, accident, and health insurance, where fixed costs tend to be sizeable; on vacation pay, which tends to have a strong seniority component; and on holiday pay; and have negative effects on overtime premiums, presumably because of high overtime rates, on sick leave and bonuses. Column 4 reports estimates of the effect of collective bargaining on the provision of fringes, using a linear probability model and the same set of controls as in previous calculations. While it would have been desireable to estimate the effect of bargaining on the probability of specific fringe programs using a more appropriate functional form, the linear model allows for a greater number of controls and, on the basis of limited experiments, appears to yield similai estimates of the impact of unionism as does a logistic model (with fewer industry and other dummy contròls). The estimates show that part of the union effect takes the form of changes in the probability of providing the fringes. Among the major fringes, trade unionism significantly raises the probability of providing pensions; by a striking .224 points in manufacturing and .272 points overa11. Unionism also raises the probability of life, acc ident \& health plans, of overtime premiums, of holiday pay, and of shift differentials, while reducing sick leave and bonuses.

Column 5 turns to fringe expenditures by establishments that have the specified fringe. It records the estimated impact of unionism from the OLS regression of fringe spending on straight-time pay and required fringes, and the standard control variables. 
These calculations isolate the impact of collective bargaining on the level of spending, conditional on provision of the given fringe. The estimates show that unionism affects the amount spent on most major fringes as well as the probability of initiating a program, with positive significant coefficients for all of the main fringes positively affected by unionism, except pension plans. In all private industrial firms. with life, accident, or health insurance programs, expenditures per manhour are $4 c$ higher in the union sector; among firms with vacation programs expenditures on pensions are $2 c$ higher; and so forth. This is consistent with the model of section I which predicts positive union effects on the average level of fringe spending as well as on the provision of fringes.

Overall, the disaggregation of fringes in table 4 shows that unionism has its greatest positive effect on fringes most likely to be favored by older infra-marginal workers, such as pensions and health, accident, and life insurance, on vacation pay, which tends to have a strong seniority component, and on holiday pay, and a negative effect on fringes which may benefit the young marginal workers the most -- sick leave (often used by young workers who are absent on Mondays or Fridays) and bonuses, which will benefit the more productive young workers most. These patterns are roughly in accord with the theoretic arguments given in section $I$.

The union effect on total compensation and on total fringe expenditures

If unionism raises fringe benefits by substantial amounts, standard estimates of the union wage effect, which for reasons of data availability are generally limited to wages, understate the full impact of collective bargaining on compensation per manhour. How large might this understatement be? Estimates of the magnitude of the bias due to neglect of the effect of unionism on fringes can be made by comparing the union coefficients from separate regressions of straight-time pay and of total compensation per manhour on collective bargaining coverage and the relevant control variables. 
With a logarithmic equation, the resultant estimates of the collective bargaining effect in the EEC sample are:

Effect of Unionism on Total:Compensation and Straight-Time Pay; EEC Sample, 1969-72

\section{All Private Industry}

Manufacturing

$\therefore$

Straight-time pay/manhour

$.148(.008)$

$.082(.011)$

Total compensation/manhour

$.173(.009)$

$.105(.011)$

Source: Regressions with full set of controls, including 50 industry dummies for all private industry and 20 industry dummies for manufacturing. See table? for list of controls.

In all private industry, the impact of unionism on total compensation is $.173,17$ percent above the impact of unionism on straight-time pay. In manufacturing, the union coefficient rises by 25 percent from .082 to .105. By these calculations, the union impact on fringes is important not only in terms of the composition of the wage bill but also in terms of the level of the union wage effect.

Finally, since unions raise straight-time pay and since straighttime pay influences fringes, the total impact of unionism on fringe spending will exceed the estimates in Tables 2-4, which hold total compensation fixed. A path model can be used, in conjunction with the estimated impact of unions on fringes and straight-time pay and of straight-time pay on fringes to obtain the total impact:

\section{(16) $b_{F U \cdot X}=b_{F U \cdot C X}+b_{F C \cdot U X}{ }^{b} C U \cdot X$}

where $b_{F U \cdot X}$ is the total effect of unionism on fringes (conditional on controls $X$ ), $b_{F U} \cdot C X$ is the union effect, holding compensation fixed, . .

$b_{F C \cdot U X}$ is the effect of compensation on fringes, holding unionism fixed, ${ }^{b} \mathrm{CU} \cdot \mathrm{X}$ is the effect of unions on compensation 
Since $b_{\mathrm{FU} \cdot \mathrm{CX}}$ is positive and $\mathrm{b}_{\mathrm{CU} \cdot \mathrm{X}}$ is positive, the total effect will exceed the estimates of the union effect conditional on compensation.

According to the $\log$ equation estimates in table 3, in all private

industry $\mathrm{b}_{\mathrm{FC} \cdot \mathrm{UX}}=1.11$ while $\mathrm{b}_{\mathrm{FU} \cdot \mathrm{CX}}=.18$; in manufacturing $\mathrm{b}_{\mathrm{FC} \cdot \mathrm{UX}}=1.16$

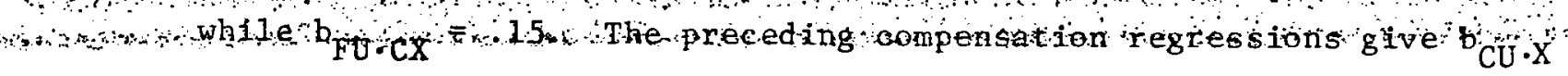
$=.17$ (a11 private) and .11 (all manufacturing). Plugging these numbers into (16) yields estimated total union effects of .36 (a11 private) and .28 (manufacturing) compared to effects via the composition of compensation of . 18 and .15. It appears that unions raise total spending on fringes roughly equally through raising the fringe share of compensation and through raising the level of compensation.

IV. Establishment Specific Factors and Spillover Effects

The analysis thus far has ignored the possibility set out earlier that omitted establishment factors correlated with unionism could be biasing the estimated coefficients. In this section I deal with the omitted variable problem by estimating equation (15) and then expand the model to allow for the possible effect of unionism on the fringes of white collar workers within an establishment. Estimates of the impact of collective bargaining on fringes turn out to be sensitive to omitted establishment factors and to the effects of blue-collar unionism on white collar fringes.

\section{Omitted Factor Model}

Columns 1 and 2 of table 5 present estimates of blue collar fringe equation (15), which adjusts for omitted establishment factors by including $1 \mathrm{nF}_{i}{ }^{\mathrm{w}}$ and the characteristics of white collar workers in the basic regression model. According to the analysis, when omitted establishment variables which raise the fringes of white collar as well as blue collar workers are correlated positively with unionism, white collar fringes will enter 
positively in the regression and the coefficient on collective bargaining will fall. In the all private industry computations in column 1 , the collective bargaining coefficient is .13 , which is $28 \%$ below the .18

obtained in table 3. In manufacturing, the collective targaining coefficient

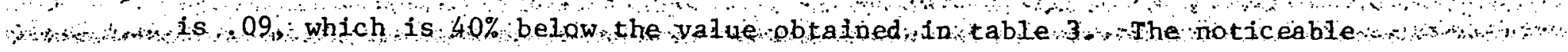
drop in the impact of unionism suggests that the previous cross-section estimates of the union impact were biased upward by omission of correlated establishment factors.

The least squares estimates of (15) do not, however, yield consistent estimates of the union effect. As pointed out in section $I$, the part of the residual in the equation that comes from the white collar fringe equation $\left(\ell_{i}{ }^{W}\right)$ is correlated with $l n F_{i}{ }^{w}$ so that when the partial correlation between $\mathrm{UN}_{i}$ and $\operatorname{lnF}_{i}{ }^{w}$ is nonzero, least squares yields a biased estimate of the coefficient on unionism. The potential magnitude of the bias can be assessed by treating $\lambda \ell_{i}{ }^{w}$ as an omitted variable correlated with $\operatorname{lnF}_{i}{ }^{w}$ and applying standard bias formula. Let $b_{\mathrm{FU}} \cdot \mathrm{X}$ be the regression coefficient of $l \mathrm{nF}^{\mathrm{W}}$ on $\mathrm{UN}_{i}$, conditional on all other variables and 1 et $\mathrm{r}_{\mathrm{FU}} \mathrm{X}$ be the accompanying partial correlation coefficient and let $P(0 \leq P \leq 1)$ be the ratio of the variance of $\ell^{w}$ to the variance of $\operatorname{lnF}_{i}{ }^{w}$. Then the bias on c due to omission of $\ell^{w}$ from the calculation is determined by (see Griliches and Ringstad, p. 197):

$$
\text { (17) } \underset{\mathrm{n} \rightarrow \infty}{\mathrm{p} \lim } \hat{\mathrm{e}}=\frac{\mathrm{bU} \cdot \mathrm{X}}{1-\mathrm{r}_{\mathrm{FU}}^{2} \cdot \mathrm{X}} \mathrm{P} \lambda+\mathrm{c}
$$

while the bias in estimating $\lambda$ is

$$
\text { (1.8) } \operatorname{plim}_{\mathrm{n} \rightarrow \infty} \hat{\lambda}=\lambda\left[1-\mathrm{P} /\left(1-\mathrm{r}^{2} \mathrm{FU} \cdot \mathrm{X}\right)\right]
$$

Regressing $l \mathrm{nF}_{i}{ }^{\mathrm{W}}$ on $\mathrm{UN}_{i}$ and all of the variables in equation (15) yields for all private industry: $b_{\mathrm{FU} \cdot \mathrm{X}}=.10 ; \mathrm{r}_{\mathrm{FU} \cdot \mathrm{X}}=.04$ and for manufacturing: $\mathrm{b}_{\mathrm{FU} \cdot \mathrm{X}}=.14 ; \mathrm{r}_{\mathrm{FU} \cdot \mathrm{X}}=.08$. Hence $\mathrm{b}_{\mathrm{FU} \cdot \mathrm{X}} /\left(1-\mathrm{r}_{\mathrm{FU} \cdot \mathrm{X}}^{2}\right)$ is .10 in all private 
Table 5: Coefficients and Standard Errors of the Effect of Collective Bargaining on the Voluntary Fringes of Nonoffice and Office Workers, Corrected for Omitted Establishment Effects

$\because \therefore \therefore \quad \therefore \quad \therefore \quad \therefore \quad \therefore \quad \therefore \quad \therefore \quad \therefore \quad \therefore \quad \therefore$

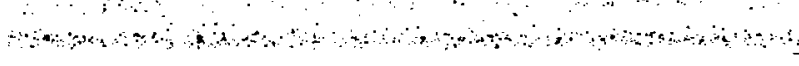

Main Variables

1. Collective bargaining

Coverage, Nonoffice Workers

2. In Compensation of

Nonoffice Workers ${ }^{a}$.

3. In Fringes of

Office Workers

4. In Compensation of

Office Workers
Nonoffice Worker Fringes

all private manufacturing industry

$\begin{array}{cc}.14 & .10 \\ (.02) & (.02) \\ 1.00 & 1.06 \\ (.02) & (.03) \\ .33 & .33 \\ (.01) & (.01) \\ -.17^{\mathrm{b}} & -.17^{\mathrm{b}} \\ (.02) & (.02)\end{array}$

10

02

\section{Other Controls}

5. Industry Dummies

50

20

50

20

6. Region SMSA Dummies

4

4

$1.91^{a}$

$1.99^{\mathrm{a}}$

$(.08)$

$(.07)$

7. Year Dummies

8. Average Characteristics

of Nonoffice Workers

9. Average Characteristics of Office Workers

10. Office/Nonoffice Employees

11. Collective Bargaining

Coverage, Office Workers

$\frac{\text { Summary Statistics }}{2}$

$\mathrm{R}^{2}$

.70

.74

.35

.36

SEE

.536

.378

.751

.571

\footnotetext{
anstrumented on straight-time pay of nonoffice workers and other variables in regression.

${ }^{b}$ Instrumented on straight-time pay of office workers and other variables in regression.
} 
industry and takes on the value of .14 in manufacturing. With these magnitudes, the coefficient on unionism will not be greatly affected by the omission of $l^{\mathrm{w}}$ unless $P$ is a very large number. The parameter $P$ is the ratio of the random (measurement error) variation of $\ln F^{\mathbf{W}}$ to the total variation in $1 \mathrm{n} \mathrm{F}^{\mathrm{w}}$ Assume that, as an upper bound, half of the variance in $\operatorname{lnF} F^{\mathrm{w}}$ is due to $\ell_{i}{ }^{\mathrm{w}}$ so that $P=1 / 2$. With this value of $P,(18)$ implies that $\hat{\lambda}$ overstates $\lambda$ by a factor of 2 , giving an estimate of $\lambda$ of $2 / 3$. With $P=1 / 2$ and $\lambda=2 / 3$, then (17) tells us that $\hat{c}$ understates $c$ by about $.03[=1 / 2(.10)]$ in all private industry and by $.05[=1 / 3(1.4)]$ in manufacturing. As a result, the impact of unionism drops to $.11(=.14-.03)$ in all private industry and to .05 in manufacturing $(=.10-.05)$. These estimates are markedly smaller than those obtained in Table 3 but still indicate that the impact of unionism is far from negligible. We conclude that, while omitted within-establishment factors may account for some of the estimated sizeable impact of collective bargaining on fringes, a substantial separate effect remains.

\section{Spillover Model}

The omitted establishment model analyzed thus far has ignored the likelihood that organization of blue-collar workers will cause firms to raise the fringes of white-collar workers. To the extent that such patterns are significant, the estimates which "correct" for omitted firm factors will bias downward the true union impact. While analysis of within-firm effects is complicated, it is possible by modifying the model of (13) to (15) to obtain a rough notion of the impact of unionism on white-collar fringes and to use the estimated impact to correct the blue-collar fringes equation for 'spillovers.' The key to a spillover analysis is a white collar fringe equation in which white-collar fringes depend not only on white-collar compensation and related variables but also on the presence of unionism in the plant:

$$
\operatorname{lnF}{ }_{i}^{w}=a^{w}+b^{w} \operatorname{lnC}{ }_{i}^{w}+c^{w} U N_{i}^{w}+s^{w} N_{i}+d^{w} X_{i}+\ell_{i}^{w}
$$


where $s^{\mathbf{W}}$ is the coefficient linking white-collar fringes to blue-collar unionism and where $E\left(U N_{i} h_{i}\right) \neq 0$, as before.

Solving (19) for $h_{i}$ and substituting into the nonoffice worker fringe equation (13) yields

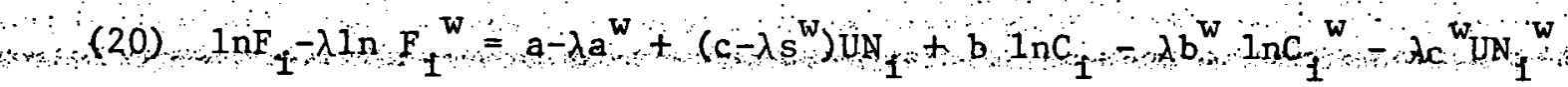

$$
+\left[d-d^{w} \lambda\right] x_{i}+\ell_{i}-\lambda \ell_{i}^{w}
$$

which is analogous to (15) except that the coefficient on $U_{i}$ no longer reflects the impact of unions on blue-collar fringes but rather the difference between the effect on blue-collar fringes and on white-collar fringes. To isolate the effect on blue collar fringes reflected in the parameter $c$, it is necessary to estimate $\lambda$ and $s^{w}$. We can estimate $s^{w}$ from (19) if some way can be found to eliminate $h_{i}$. The most direct approach is to expand the model to include an equation for total white-collar compensation:

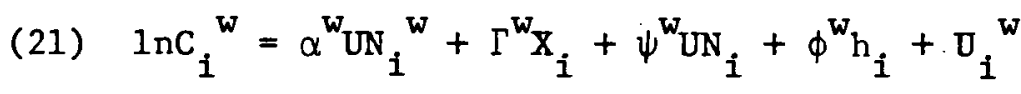

where the compensation of white collar workers depends on unionism of blue collar workers through $\psi^{w}$, on their own (negligible) organization through $\alpha^{w}$, on the other factor $\mathrm{X}$, and on the omitted establishment factor, with a scaling factor $\phi^{\mathbf{w}}$ which permits a different establishment effect on total compensation than on fringes.

Now (21) can be solved for $h_{i}$ and the resultant expression substituted into (19) to obtain an equation relating the fringes of white collar workers to the unionism of blue collar workers with the omitted establishment factor eliminated:

$$
\begin{aligned}
& \ln F_{i}^{w}=a^{w}+\left(s^{w}-\psi^{w} / \phi^{w}\right) U N_{i}+\left(b^{w}-\phi^{w}\right) \operatorname{lnc}{ }_{i}^{w}+\left(c^{w}-1 / \phi^{w}\right) U N_{i}{ }^{w} \\
& \left.\left(d^{w}-\Gamma^{w}\right) \phi^{w}\right) X+\ell_{i}^{w}-U_{i}^{w} / \phi^{w}
\end{aligned}
$$

Since $\mathrm{E}\left(\mathrm{U}_{i}{ }^{\mathrm{w}_{\mathrm{C}}}{ }_{i}{ }^{\mathrm{w}}\right) \neq 0$, however, ordinary least squares estinates of will yield biased coefficients. To correct for this, an instrument is. needed which is correlated with $C_{i}{ }^{w}$ but not with $U_{i}{ }^{w}$ or $\mathcal{L}_{i}{ }^{w}$. The obvious 
candidate is the compensation of blue collar workers $C_{1}$ since $E\left(C_{1} C_{i}^{W}\right) \neq 0$ while $E\left(C_{i} U_{i}^{w}\right)=E\left(C_{i} l_{i}^{w}\right)=0$.

Instrumental variable estimates of (22) are given in columns 3 and 4 , of table 5. Note that in these equations the 1 n compensation of office workers is instrumented on the $1 n$ compensation of nonoffice workers, in accord with the preceding argument, whereas in the equations for nonoffice worker fringes in the table, In compensation of office workers was instrumented on the ln straight time pay of office workers. The estimates reveal a moderate impact of unionism on white collar fringes, ranging from .10 in manufacturing to .13 in all industry. From these calculations, there would appear to be some validity to the industrial relations belief that trade unionism affects the compensation package of white as well as blue collar workers.

In the spillover model the coefficient on collective bargaining in equation (15) is the difference between the union impact on blue collar fringes and the multiplicand of the union impact on white collar fringes and the within establishment $\lambda$ parameter:

(23) $\hat{b}=c-\hat{\lambda} \hat{s}^{w}$ so that $c=\hat{b}+\hat{\lambda} \hat{s}^{w}$, We can solve (23) for the desired parameter using the estimates in table 5. In all private industry, the coefficient of collective bargaining $(\hat{b})$ in the nonoffice worker equation is .14; the coefficient of collective bargaining in the office worker equation $\left(\hat{s}^{\mathrm{W}}\right)$ is .13 . The estimated value of $\lambda$, the enterprise specific parameter, is .33 but, by the arguments given earlier, the actual value of $\lambda$ may be as high as two-thirds. With $\hat{b}=.14, \hat{s}^{w}=.13$ and $\lambda=.33$, the estimate of $c$ is .17 . With $\hat{b}=.14$, $\hat{s}^{w}=.13$ and $\hat{\lambda}=.67$, the estimate of $c$ is .23 . In manufacturing where $\hat{b}=.07$ and $\hat{s}^{w}=.10, c$ is estimated to be .10 when $\lambda=.33$ and to be .14 when $\lambda$ is .67 . Taking account of the impact of unionism on white collar fringes raises the estimated effect on blue collar fringes in the omitted enterprise factor model to levels approaching those in the cross- 
section regressions of table 3.

An important property of the new model is that the effect of unionism is essentialiy invarlant to the within-establishnent parameter $\lambda$. Larger values of $\lambda$ reduce the estimate of $b$ but also raise $s_{w} \lambda$, with the result that the union coefficient remains about the same. Table 6 explores the invariance of the estimated union effects in terms of estimates of the components of (23), conditional on specified values of $\lambda$. Line 1 records predetermined values of $\lambda$. Line 2 gives the coefficient (and standard error) on unionism from the resultant regression of $\operatorname{lnF}_{i}-\lambda \ln F_{i}$ on the various explanatory factors. As the value of $\lambda$ increases, the estimate of $c-\lambda s^{w}$ drops, particularly in manufacturing. . Line 3 records the values of $s^{w}$ from table 5. Line 4 uses (23) to obtain the final estimate of $c$. The calculations show that while $c-\lambda s^{w}$ varies greatly with different values of $\lambda, c$ does not. According to the final figures, unionism raises fringe spending, all other factors the same, by from .18 to .20 $10 \mathrm{~g}$ points in all private industry and by .10 to .13 points in manufacturing.

The estinates of the spillover model suggest that blue collar unionisn may have a sizeable impact on white collar fringes, making the 'brothers' type of correction for within-establishment omitted factors incorrect. The estimates should, however, be viewed solely as illustrative of potential magnitudes of spillover impacts and not as a test of the existence of spillovers. The model of (19)-(23) provides no test of the direction of causality of the linkages (any more than did the omitted factor model in Table 5); it measures the union influences solely by presence of a contract in the plant, rather than by provision of specific fringes; and it was not based on the type of case histories that might provide sufficiently strong prior knowledge to permit definite conclusions from the calculations.

These errors of omission notwithstanding, the model does suggest the possibility that unionism affects white-collar as well as blue-collar 
Table 6

Estimates of the Effect of Unionism on the Fringes of

Nonoffice Workers, with Establishment Specific

and Union Spillover Effects, Conditiona on Values of $\lambda$

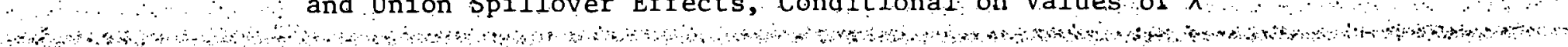

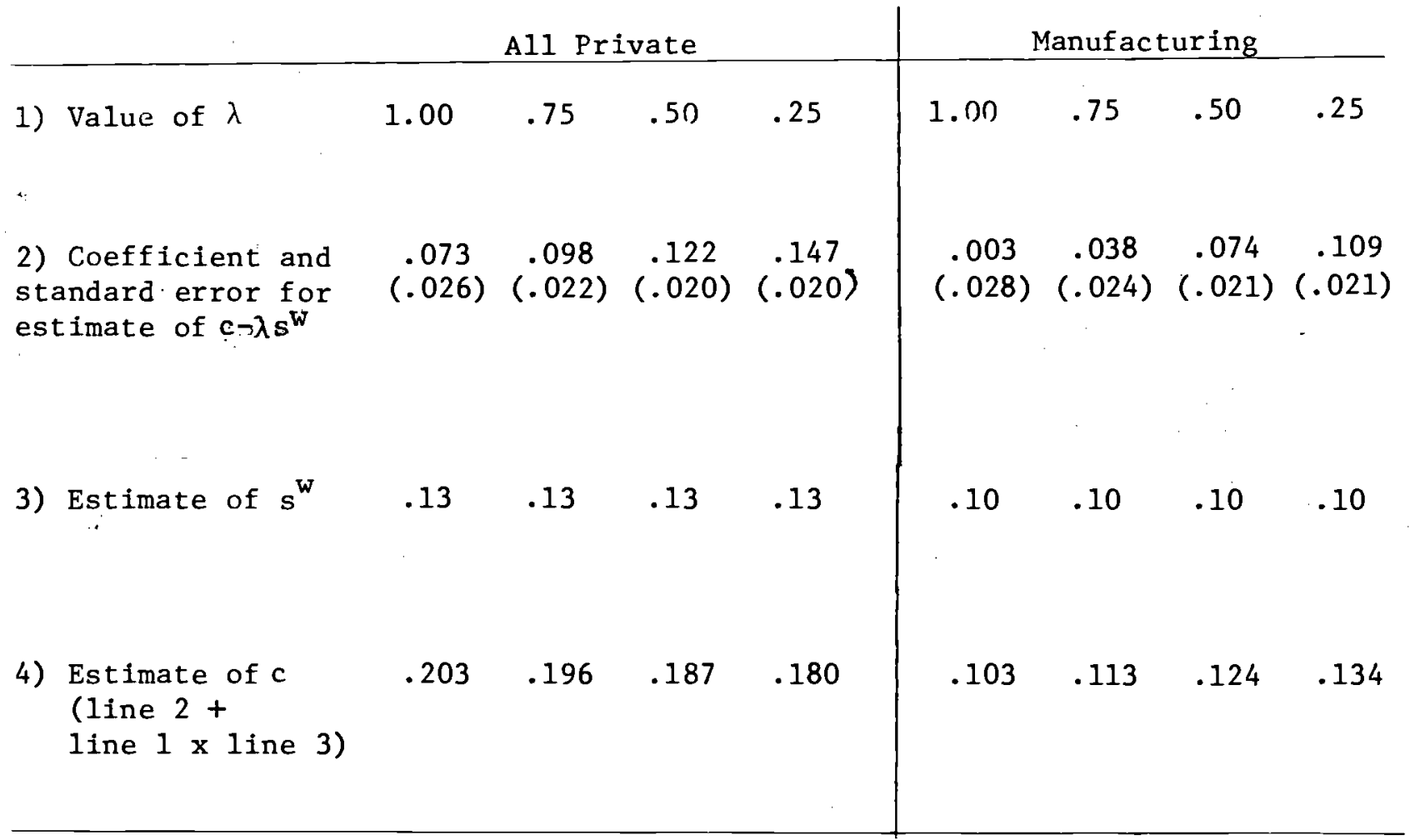

Source:

line 2, Based on regression of $\ln F_{i}{ }^{B}-\lambda \operatorname{lnF}{ }_{i}{ }^{W}$ on union dummy and other independent variables: In compensation of office workers, in compensation of nonoffice workers (instrumented on straight-time pay), 4 region SMSA dummies, 5 year dummies, ratio of office to nonoffice employees, average characteristics of office and nonoffice workers and 50 (20) industry dummies in all private industry (manufacturing).

line 3, nhtalned from regression of in fringes of whitc-collar workers in unionism and control variables, as given in table 5. 
fringes and highlights the danger of allotting all of the link between white-collar fringes to omitted firm factors.

V. Conclusion

The analysis and findings of this paper can be summarized briefly:

(1) Because of the political nature of unionism, which makes them more representative of average then of marginal worker preferences and more sensitive to intensities of preference; and because of the role of unions as stable market institutions; and possibly because unions provide more accurate information about worker preferences for fringes than can be garnered fron individual bargaining, unionism can be expected to raise the fringe share of the compensation package; (2) Estimates of the impact of unionism on the fringes of blue collar workers show the expected effect, with the magnitude depending on the particular statistical model used for estimation. The estimated effect of unionism is sizeable in regressions which compare organized and nonorganized establishment.s; are reduced when omitted firm factors are taken into account; but are raised when allowance is made for the possible effect of blue-collar unions on the fringes paid whitecollar workers in the same establishment; (3) The effect of unionism on fringes is especially large for deferred compensation like pensions, life, accident and health insurance, in accord with a priori expectations, and is greater for low wage and small firms; (4) Because of the sizeable impact of unionism on fringes and the importance of fringes in the wage bill, standard estimates of the union wage effect understate the differential between unionized and otherwise comparable nonunion workers. 


\section{Footnotes}

IFor a detailed discussion of the survey see U.S. Bureau of Labor

Statistics, Handbook of Methods (Bulletin 1910, Washington D.C., U.S.

Government Printing office, 1976).

${ }^{2}$ If $\bar{c}$ is the fixed cost of instituting the program, the cost function

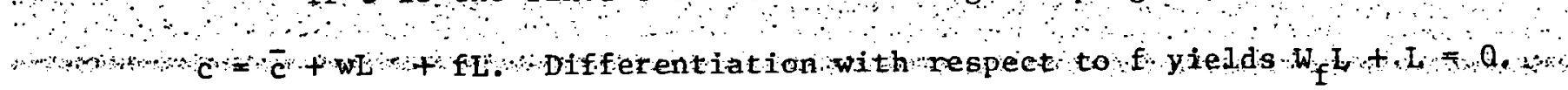

This model assumes that the firm is indifferent between paying fringes or paying hourly rates. See pages $8-9$ for a discussion of why firms might prefer one form of compensation over the other.

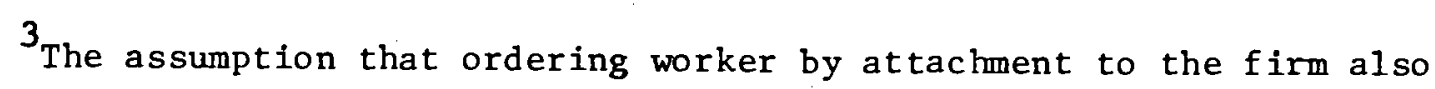
orders them by preferences for fringes is the key assumption in the analysis. In the model all workers of the same tenure with a firm are treated as if they had the same preference for fringes, making the difference in tenure the sole cause of different desires. When worker preferences for fringes differ for reasons unrelated to attachment to the firm, the competitive market will produce different sets of compensation packages, with more fringes in some establishments to attract those preferring fringes, and less in others. Variation of this type is ignored to concentrate on the situation in which preferences differ by potential mobility or tenure in the firm.

${ }^{4}$ See W. Kip Viscusi (1977) for detailed discussion of this maximized in the context of work quality.

5eontief's 1946 article on the guaranteed annual wage makes this argument using the standard Edgeworth box.

The information argument can be investigated further by analyzing the extent to which, other factors fixed, union negotiated fringes "spillover" to nonunion firms. Since the nonunion firm will imitate the union employer only if workers prefer the allocation of the wage bill in the union sector, the existence of a positive spillover could be taken as evidence of a better information flow. If there were no additional information about preferences in the union package, nonunion firms would not be influenced 
by the composition of the union settlement.

7

The union variable is coded 1 if $50+$ percent of nonoffice workers (or office workers) are covered by collective bargaining. While this implies that some workers who are not covered by contracts are included while some who are not are counted as nonorganized, B.L.S experts" report that the assumption that all are covered when $50+$ percent of the nonoffice workers are covered and that none are covered in establishments when less than 50 percent are covered is reasonable:

${ }^{8}$ Since the regressions deal with establishments and include size variables, there is no reason to expect any major problems.

${ }^{9}$ The May CPS files were used because union membership is included in the May survey. The estimates were obtained from the basic data using unweighted counts of union and nonunion members.

${ }^{10}$ Omission of the variable had little effect on the results.

11 The problem is identical to that of estimating a consumption function in which $C$ is regressed on $Y$, where $Y=C+I$.

12 The scaling factor is, of course, arbitrary as the variable is unobserved. ${ }^{13}$ Since we have scaled $h_{i}$ to have an effect of $i$ For blue collar workers, on alternative scale must be used if we are to permit the omitted factor to affect the two groups of workers differently. A scaling of 1 has the virtue of algebraic simplicity.

14 An alternative way to handle the consistency problem is to specify a priori values of $\lambda$, save $\lambda \operatorname{lnf}_{i}{ }^{w}$ to the 1 eft hand side, and estimate the resultant equation by least squares. With $\operatorname{lnf}_{i}{ }^{\mathrm{w}}$ as part of the dependent variable, $\ell_{i}{ }^{\beta}-\lambda \ell_{i}{ }^{w}$ is uncorrelated with the explanatory variables. While in many problems, a value of $\lambda=1.0$ can be defended in terms of the definetti exchangeability criterion this is not the case in the current problem. Blue-collar and white-collar workers are identifiably different and there is no reason to expect firm 'patemalism' to treat them identically. Table 6 gives estimates conditional on prior values of $\lambda$. 
Alchian, A. and Demsetz, H. "Production, Information Costs, and Economic Organization," AER, December 1972, Pp. 777-796.

Bureau of Labor Statistics, BLS Handbook of Methods, Bulletin 1910. (Washington,

D.C.: U.S. Government Printing Office), 1976.

Chamberlaiñ, G. "An Instrumental Variable Interpretation of Identification in

Variance-Components and MIMIC Models," in P. Taubman, ed., Kinometrics:

The Determinants of Socio-Economic Success Within and Between Families

(Amsterdam: North-Holland Publishing Co.), 1977.

Freeman, R.B., "Individual Mobility and Union Voice in the Labor Market," AER,

Vo1. 66, No. 2, May 1976, pp. 361-368.

Griliches, Z. and V. Ringstad, Economies of Scale and the Form of the Production

Scale (Amsterdam: North Holland Publishing Co.), 1971.

Herman, N., "Labor Union Participation and Compensation Preferences of Workers,"

(Harvard thesis), 1978.

Hirschman, A., "Some Uses of the Exit-Voice Approach -- Discussion," AER, Vol. 66, No. 2, May 1976, pp. 386-389.

Lawler, E. and E. Levin, "Union Officers' Perception of Members' Pay Preferences," ILRR, July 1968, pp. 589-617.

Leontief, W.W., "The Pure Theory of the Guaranteed Annual Wage," JPE, 1946.

Lester, R., "Benefits on a Preferred Form of Compensation," Southern Economics Journa1, Vo1. XXXIII, No. 4, April 1967, pp. 488-495.

Nealey, S.M., "Pay and Benefit Preference," Industrial Relations, Vol. III, October 1963, pp. $17+28$.

Nelson, R.C., "Some Uses of the Exit-Voice Approach -- Discussion," AER, Vo1. 66, No. 2, May 1976, pp. 389-391.

Reynolds, L.G., Labor Economics and Labor Relations (New Jersey: Prentice Hal1), 1974.

Rice, R., "Skill, Earnings and the Growth of Wage Supplements" AER, May 1966, pp. 583-593.

Slichter, S.H., Healy, J.J. and Livernash, E.R., The Impact of Collective Bargaining on Management (Washington, D.C.: The Brookings Institution), 1960.

Viscusi, W.K., "Unions, Labor Market Structure, and the Welfare Implications of the Quality of Work," processed, 1977. 